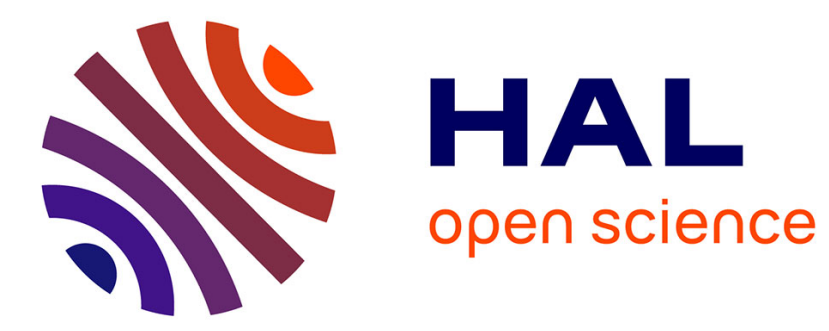

\title{
Forming a cold electron population at a weakly outgassing comet
}

Peter Stephenson, Marina Galand, Jan Deca, Pierre Henri, Gianluca Carnielli

\section{To cite this version:}

Peter Stephenson, Marina Galand, Jan Deca, Pierre Henri, Gianluca Carnielli. Forming a cold electron population at a weakly outgassing comet. Europlanet Science Congress 2021, Sep 2021, Virtual Meeting, Unknown Region. 10.5194/epsc2021-823 . hal-03536595

\section{HAL Id: hal-03536595 \\ https://hal.science/hal-03536595}

Submitted on 21 Jan 2022

HAL is a multi-disciplinary open access archive for the deposit and dissemination of scientific research documents, whether they are published or not. The documents may come from teaching and research institutions in France or abroad, or from public or private research centers.
L'archive ouverte pluridisciplinaire HAL, est destinée au dépôt et à la diffusion de documents scientifiques de niveau recherche, publiés ou non, émanant des établissements d'enseignement et de recherche français ou étrangers, des laboratoires publics ou privés. 
EPSC Abstracts

Vol. 15, EPSC2021-823, 2021

https://doi.org/10.5194/epsc2021-823

Europlanet Science Congress 2021

(C) Author(s) 2022. This work is distributed under

the Creative Commons Attribution 4.0 License.

\title{
Forming a cold electron population at a weakly outgassing comet
}

\author{
Peter Stephenson ${ }^{1}$, Marina Galand ${ }^{1}$, Jan Deca ${ }^{2}$, Pierre Henri ${ }^{3,4}$, and Gianluca Carnielli ${ }^{1}$ \\ ${ }^{1}$ Department of Physics, Imperial College London, London, UK \\ ${ }^{2}$ Laboratory for Atmospheric and Space Physics, University of Colorado, Boulder, Colorado \\ ${ }^{3}$ Lagrange, OCA, CNRS, UCA, Nice, France \\ ${ }^{4}$ LPC2E, CNRS, Orleans, France
}

The Rosetta Mission rendezvoused with comet 67P/Churyumov-Gerasimenko in August 2014 and escorted it for two years along its orbit. The Rosetta Plasma Consortium (RPC) was a suite of instruments, which observed the plasma environment at the spacecraft throughout the escort phase. The Mutual Impedance Probe (RPC/MIP; Wattieaux et al, 2020; Gilet et al., 2020) and Langmuir Probe (RPC/LAP; Engelhardt et al., 2018), both part of RPC, measured the presence of a cold electron population within the coma.

Newly born electrons, generated by ionisation of the neutral gas, form a warm population within the coma at $\sim 10 \mathrm{eV}$. Ionisation is either through absorption of extreme ultraviolet photons or through collisions of energetic electrons with the neutral molecules. The cold electron population is formed by cooling the newly born, warm electrons via electron-neutral collisions. Assuming the radial outflow of electrons, the cold population was only expected at comet 67P close to perihelion, where outgassing rate from the nucleus was at its highest $\left(\mathrm{Q}>10^{28} \mathrm{~s}^{-1}\right)$. However, cold electrons were observed until the end of the Rosetta mission at 3.8au when the outgassing was weak $\left(\mathrm{Q}<10^{26} \mathrm{~s}^{-1}\right)$. Under the radial outflow assumption, there should not have been sufficient neutral gas to efficiently degrade the electron energies.

We have developed the first 3D collision model of electrons at a comet. Self-consistently calculated electric and magnetic fields from a collisionless and fully-kinetic Particle-in-Cell model (Deca et al., 2017; 2019) are used as a stationary input for the test particle simulations. We model the neutral coma as a spherically symmetric cloud of pure water, which follows $1 / r^{2}$ in cometocentric distance. Electron-neutral collisions are treated as a stochastic process using cross sections from Itikawa and Mason (2005). The model incorporates elastic scattering of electrons and a variety of inelastic collisions, including excitation and ionization of the water molecules.

We show that the radial outflow of electrons from the coma is insufficient to generate a cold electron population under weak outgassing conditions. Using our original test particle model, we demonstrate the trapping of electrons in the inner coma by an ambipolar electric field and how this increases the efficiency of the electron cooling. We also show that, at low outgassing rates, electron-neutral collisions significantly cool electrons within the coma and can lead to the formation of a cold population. 
